\title{
25 Research Soure \\ Identification of an SRY-Negative 46,XX Infertility Male with a Heterozygous Deletion Downstream of SOX3 Gene
}

Shengfang Qin ( $\sim$ qinshengfang@126.com )

Chengdu Medical College https://orcid.org/0000-0001-9391-890X

\section{Xueyan Wang}

Chengdu Medical College

Jin Wang

Chengdu Medical College

\section{Research Article}

Keywords: 46,XX male, SRY-negative, fluorescence in situ hybridization, chromosome microarray chip, whole genome analysis, sex development and differentiation, pathogenicity, mutations

Posted Date: November 10th, 2021

DOI: https://doi.org/10.21203/rs.3.rs-1013566/v1

License: (a) (1) This work is licensed under a Creative Commons Attribution 4.0 International License. Read Full License

Version of Record: A version of this preprint was published at Molecular Cytogenetics on February 14th, 2022. See the published version at https://doi.org/10.1186/s13039-022-00580-7. 


\section{Abstract}

Background: A male individual with a non-chimeric karyotype of $46, X X$ is very rare. We explored the genetic aetiology of an infertility male with $46, \mathrm{XX}$ and $S R Y$ negative.

Methods: The peripheral blood sample was collected from the patient and subjected to a range of genetic testing, including conventional chromosomal karyotyping, short tandem repeat (STR) analysis for chromosome 13, 18, 21, X, Y contained SRY gene, azoospermia factor (AZF) deletion analysis including $S R Y$ gene, fluorescence in situ hybridization (FISH) with specific probes for CSP X/CSP Y/SRY, chromosomal microarray analysis (CMA) for genomic copy number variations (CNVs), and wholegenome analysis(WGA) for SNV\&InDel variants, and the $\mathrm{X}$ chromosome inactivation $(\mathrm{XCl})$ analysis for $A R$ gene.

Results: The patient was found to have a 46,XX karyotype. Neither $A Z F a+b+c$ nor $S R Y$ band was detected in the electrophoresis result. FISH results of both interphase cells with CSPX/CSPY probe and metaphase cells with CSPX/CSPY/SRY probe showed two green fluorescence signals at the centromeres of $X$ chromosomes, but no Y chromosome and $S R Y$ fluorescence signal. QF-PCR results showed that the patient had only the AMELX fluorescence peak of the X chromosome but no AMELY and SRY fluorescence peak. All results of the Karyotype, FISH, and STR did not suggest limited Y chimerism. CMA showed he had a heterozygous deletion of about 867 kb in Xq27.1 (hg19: chrX: 138,612,879-139,480,163 bp), located at $104 \mathrm{~kb}$ downstream of SOX3 gene, including F9, CXorf66, MCF2 and ATP11C, Meanwhile, whole-genome sequencing also found no SNV\&InDel mutation associated with abnormal sex development. $75 \% \mathrm{X}$ chromosome inactivation was detected.

Conclusions: Although the pathogenicity of $46, \mathrm{XX}$ male patients with $S R Y$ negative remains unclear, SOX3 expression of the acquired function may be associated with partial testis differentiation. Therefore, copy number variation of $\mathrm{SOX} 3$ gene and regulatory region should be performed routinely for these patients.

\section{Background}

XX male sex Reversal (46,XX sex Reversal, SRXX) is a disease caused by the abnormalities of ovarian development, characterized by $46, X X$ karyotype and male phenotype, which is often referred to as $46, X X$ male[1]. The incidence rate in male newborns is about $1 / 20,000$ [2]. It has been reported that over $90 \%$ of $46, \mathrm{XX}$ male genomes contain $S R Y$ gene that is $46, \mathrm{XX}(S R Y+)$ male, which is often caused by the translocation of $Y$ chromosome fragment containing $S R Y$ gene to $X$ chromosome[3-7]. Among the remaining $10 \%$, a very few are $46, \mathrm{XX}$ males without $S R Y$ gene, namely $46, \mathrm{XX}(S R Y$-) males exclusive of the $\mathrm{Y}$ chromosome chimerism[8,9].

In previous reports, the causes of $46, \mathrm{XX}(S R Y$-) male mainly include dose change or mutation of SOX9 gene[9-12], loss of function mutation of ovarian stimulating gene WNT4 or RSPO1 gene[13,14], heterozygous mutation of NR5A1 gene[15-17], recently there are also a few reports about the copy number variation(CNV) of SOX3 (SRY-box transcription factor 3) gene[18]. Here, we will proceed with the 
molecular genetic identification of a $46, \mathrm{XX}(S R Y$-) male patient admitted to our clinic, and the research results will enrich the theoretical knowledge and guide the clinical treatment of this kind of patient.

\section{Methods}

\section{Subject}

A 31-years-old patient, heigh $166 \mathrm{~cm}$ and weigh $52.5 \mathrm{~kg}$, went to our clinic due to primary infertility. Physical examination showed a male appearance, a thin beard, Adam's apple, two broad bean-size of testicles and an average size of the penis. No sperm was found in routine semen examination. Hormone test results were follow: Testosterone: $1.75 \mathrm{ng} / \mathrm{mL}$ (reference value range(RVR): $2.80-8.00)$, progesterone: $0.11 \mathrm{ng} / \mathrm{mL}$ (RVR: $0.20-1.40)$, prolactin: $208.44 \mathrm{ulU} / \mathrm{mL}$ (RVR: 86.00-324.00), estradiol: $5.00 \mathrm{pg} / \mathrm{mL}$ (RVR:27.10-52.20), luteinizing hormone: $29.32 \mathrm{mlU} / \mathrm{mL}(\mathrm{RVR}: 1.70-8.60)$, follicle-stimulating hormone $37.88 \mathrm{mIU} / \mathrm{mL}$ (RVR: 1.50-12.40). Deny genetic history. The parents of the patient refused the karyotype analysis.

\section{Specimen preparation and DNA extraction}

$5 \mathrm{~mL}$ of venous blood was collected from patients with heparin sodium and EDTA-Na 2 anticoagulant tubes, respectively, and ready for use. According to the manufacturer's protocols, genomic DNA was extracted from EDTA-Na ${ }_{2}$ anticoagulated blood using QIAamp DNA Mini Kit (QIAGEN Company). DNA was qualified when the concentration was more than $30 \mathrm{ng} / \mathrm{uL}$, the OD260/280 value between 1.8 to 2.0 determined by ultraviolet spectrophotometer Nanodrop 1C (Thermo Fisher Scientific).

\section{Chromosome karyotype analysis}

Lymphocytes of heparin sodium anticoagulated blood were cultured, harvested, and prepared for microscope slides before Giemsa staining according to conventional cell culture methods. Zeiss karyotype analysis system (Karl Zeiss,Germany) was adopted for chromosome count and karyotype analysis, the same as previous studies[19].

\section{AZF detection}

Multiplex amplified was performed with AZF detection kit (Yaneng corp.), then $2.0 \%$ agarose electrophoresis and imaging, according to manufacturer's instructions.

\section{QF-PCR detection}

Multiplex PCR amplification was performed with Devyser compact v3 kit (Devyser AB, Sweden). The amplification condition was $95^{\circ} \mathrm{C}$ for $15 \mathrm{~min} ; 94^{\circ} \mathrm{C} 30 \mathrm{sec}, 58^{\circ} \mathrm{C} 1 \mathrm{~min} 30 \mathrm{sec}, 72^{\circ} \mathrm{C} 1 \mathrm{~min} 30 \mathrm{sec}, 27$ cycles; $72{ }^{\circ} \mathrm{C}$ for $30 \mathrm{~min}$. The amplified products were subjected to capillary electrophoresis with $\mathrm{AB}$ 3500Dx gene analyzer, and the electrophoresis data were analyzed by GeneMapper software. The fluorescence peak of AMELX in Xp22.2, AMELY in Yp11.2 and SRY in Yp11.31 were used to evaluate the patient's gender. The experimental method was referred to in the previous report[20]. 


\section{FISH analysis}

Lymphocytes in EDTA-Na2 anticoagulant blood were isolated by lymphocyte separation solution and hybridized by CSP18/CSP X/CSPY probe (Jin Pujia corp.), as the same method as previously reported[21]. Meanwhile, the metaphase cells harvested from lymphocyte culture were co-hybridized with CSPX/CSPY probe (Jinpuga Company) and SRY probe (Abbott Company). The MIX-1 was prepared by $S R Y$ hybridization buffer and $S R Y$ probe at a ratio of 9:1, and the MIX-2 was made with CSP hybridization buffer and CSP X/CSP Y centromeric probe at a ratio of 4:1, and then added the MIX-1 and MIX-2 to the metaphase cells loaded on the glass slide. The Glass slide was denaturated at $78^{\circ} \mathrm{C}$ for 10 minutes and hybridized at $42^{\circ} \mathrm{C}$ for more than 16 hours. Refer to reagent instruction for the experimental operation. A fluorescence microscope observed the fluorescence signal of hybridization.

\section{CMA analysis}

500-1000ng of patient DNA and the equivalent amount of reference DNA was taken for simultaneous experiments. After digestion, the labelled patient sample was mixed with the reference sample and cohybridized to SurePrint G3 CGH+SNP (180K) chip. Agilent DNA Microarray Scanner was used to scan the fluorescence signals after the slides were washed. Agilent Feature Extraction Software extracted the data from the images(.tif) and converted it to log-ratios data. Agilent CytoGenomics software was used to analyze CNV. Agilent Technologies provide the reagents, chips, instruments and analytical software. Refer to the instructions for specific methods. CMA analysis mainly adopts some online databases such as OMIM (https://omim.org/), DGV (http://dgv.tcag.ca/dgv/), Decipher (https://decipher.sanger.ac.uk/), ClinGen (https://wwW.clinicalgenome.org/), ClinVar (https://www.ncbi.nlm.nih.gov/clinvar/).

\section{WGA analysis}

Illumina HiSeq PE150 high-throughput dual-terminal sequencing was performed after random interruption into tiny fragments of DNA, terminal repair, phosphorylation, a-tail addition, connector and library construction. Quality control was carried out on the raw sequencing data to obtain high-quality clean data; Then, fastp software[22] was used for comparative analysis of clean data and human reference genome sequence, and data such as sequencing depth and coverage of the target region were counted and obtained Bam files. Finally, SNP/InDel was detected and annotated based on Bam files to obtain all mutation information. The Haplotyper tool of Sentieo software[23] was used to detect SNP and InDel mutation, and ANNOVAR software[24] was used to annotate the mutation results accompanied by multiple databases (such as dbSNP, 1000G, ESP6500, HGMD, OMIM). Meanwhile, CNVkit software was used to analyze CNV[25].

\section{$\mathrm{XCl}$ detection}

The sample DNA of undigested and digested by Hpall, which methylation-sensitive restriction enzyme, was amplified by androgen receptor $(A R)$ gene-specific primers and capillary electrophoresis subsequently. MIC2 was used as the reference gene, and the Hpa II enzyme was digested overnight in a $37^{\circ} \mathrm{C}$ water bath. The samples were amplified by double PCR before and after enzyme digestion. As 
reported in the literature[26], FAM fluorescein was added to the 5 'end of the forward primer[27]. PCR reaction conditions followed: $95^{\circ} \mathrm{C}$ for $5 \mathrm{~min} ; 28$ cycles of $95^{\circ} \mathrm{C}$ for $45 \mathrm{sec}, 58^{\circ} \mathrm{C}$ for $30 \mathrm{sec}, 72^{\circ} \mathrm{C}$ for $30 \mathrm{sec} ; 72^{\circ} \mathrm{C}$ for $7 \mathrm{~min}$. PCR products were subjected to capillary electrophoresis. $\mathrm{XCl}$ ratio was calculated according to formula (d1/u1)/(d1/u1 + d2/u2), and $>70 \%$ was determined as $\mathrm{XCl}$ bias[28,29].

\section{Results}

\section{Cytogenetic analysis}

The patient's karyotype was $46, \mathrm{XX}$, as shown in Figure.

\section{$A Z F$}

Electrophoresis results of the amplification products of patients showed no $S R Y$ bands nor corresponding bands of $A Z F a$ (sY84, sY86), AZFb (sY127, sY134), and $A Z F c$ (sY254, sY255) regions.

QF-PCR

The gender site of the patient was $A M E L X$ but not $A M E L Y$, and there was no fluorescence peak at the $S R Y$ site, as shown in Figure 2.

\section{FISH analysis}

FISH results of interphase cells hybridized by the centromere probes of $18, X$ and $Y$, showed two 18 and two $X$ fluorescence signals but no $Y$ signal, as shown in Figure 3A. FISH results of metaphase cells hybridized with $\mathrm{X}, \mathrm{Y}$, and $S R Y$ probes showed two green signals of $\mathrm{X}$ chromosome centromere, but neither of $S R Y$ nor $Y$ chromosome, as shown in Figure $3 b$.

\section{Results of Y chromosome chimerism}

No Y chimerism was detected by karyotype analysis, CSPY analysis in FISH, and AMELY and SRY analysis in QF-PCR.

\section{CMA}

Taking 46,XX normal females as a reference, the patient's Xq27.1 (hg19: chrX: 138,612,879-139,480,163 bp) had about $867 \mathrm{~Kb}$ of heterozygotic deletion, and the deletion region was located at $104 \mathrm{~Kb}$ downstream of the SOX3 gene, including F9, CXorf66, MCF2, ATP11C four protein-coding genes, as shown in Figure $4 \mathrm{a}$ and $4 \mathrm{~b}$.

\section{WGA}

The WGA results showed no pathogenic or likely pathogenic SNV\&InDel variant related to sexual development, which can clearly explain the patient phenotype; meanwhile, the results also showed about 892kb heterozygous deletion (hg19: chrX: 138,609,392-139,501,392) in Xq27.1. 
$\mathrm{XCl}$

The $\mathrm{XCl}$ ratio of patients was about 75\%, which was non-random inactivation. See Figure 5.

\section{Comparison of the clinical phenotypes of $46, X X S R Y$-negative male patients with CNV of SOX3}

Table 1 summarises the clinical features of $46, X X$ males with $S R Y$-negative individuals involved in the CNV of SOX3. The patients all had the typical male appearance and showed common abnormal phenotypes, including spermatogenous testicular dysplasia because they were absent from the entire $Y$ chromosome. Among the seven patients, five patients(case 1, 3, 4, 5, 6) had microduplications spanning the entire SOX3 gene, another two patients, including the case 2 and our patient, had microdeletions near the SOX3 gene, which were speculated to play a regulatory role for SOX3 expression. Our patient showed a CNV near the SOX3 gene in CMA, and WGA excluded no other SNV\&InDel mutations associated with sex development. Meanwhile, he had a skewed $\mathrm{X}$ chromosome inactivation, which was not inconsistent with the case 1.

\section{Discussion}

$S R Y$ gene is recognized as the best TDF candidate gene. As long as the $S R Y$ gene exists in the individual genome, male gonadal development will occur even without the $Y$ chromosome, the primary mechanism of $46, \mathrm{XX}(S R Y+)$ male pathogenesis. Therefore, $\mathrm{Y}$ chromosome chimerism in $46, \mathrm{XX}(S R Y-)$ males should be excluded first. This study detected no $\mathrm{Y}$ chromosome chimerism in the patient's peripheral blood through several experimental analysis methods. Of course, it was impossible to rule out completely the gonad limited chimerism due to the inability to obtain the gonad tissue. Other gene mutations may cause the pathogenesis of $46, \mathrm{XX}(S R Y$-) males in the testicular development pathway, which makes the gonads of individuals without the $S R Y$ gene develop towards the testis[4,5].

Some $46, \mathrm{XX}(S R Y-)$ male individuals were previously reported to be caused by abnormalities of the SOX3 gene[9] and found the repetition of the SOX3 regulatory region can up-regulate SOX9 gene expression[30]. In our patient, There is a heterozygous deletion near the SOX3 gene in Xq27.1, which may be related to its pathogenesis.

SOX3 gene is one of $20 \mathrm{SOX}$ (SRY-related HMG-box) gene family members. Stevanovic et al. cloned the SOX3 gene and identified its location at Xq27.1 in 1993[31]. SOX3 gene consists of a single exon and contains an HMG box, encoding 446 amino acids of a transcription factor SOX-3 protein[32]. SOX3 gene sequence is highly conserved among different species and has high homology with $S R Y$ and other SOX family genes. SOX3 gene is the ancestral gene of the $S R Y$ gene[9,33]. SOX3 encodes a transcription factor expressed in the central nervous system of vertebrate embryos[32], which plays a vital role in the pituitary, craniofacial and adrenal development. The variation of this gene is associated with X-linked mental retardation, growth hormone deficiency, X-linked hypothyroidism, 46,XX male sex reversal, and other diseases[9,34-37]. 
Loss-of-function of SOX3 induced by mutation does not cause sex determination abnormality in mice and humans[38]. However, studies in transgenic mice have shown that in-situ expression of SOX3 in bipotent gonads leads to up-regulation of Sox9 expression, leading to testicular induction and XX male sex reversal. The mechanism of SOX3 rearrangement causes sex reversals, and the frequency of sex development disorders remain unknown. The study of Moalem $S$ et al. provided evidence that the de novo duplication of SOX3 in XX bipotent gonads causes the acquisition of SOX3 function[39]. In XX mice lacking the $S R Y$ gene, it was found that the expression of the $S O X 3$ gene with the acquired function was related to partial differentiation of testis. Overexpression of SOX3, synergistically expression with SF1, upregulated SOX9 stimulated gonad development into testis in XX mice[9,40]. SRY gene was derived from a new mutation in the regulatory region of the SOX3 gene and expressed in the early gonad. The data of transgenic mice indicated that $S O X 3$ and $S R Y$ were interchangeable in sex determination function.

The type of variation in SOX3 that has been associated with $46, X X$ male sex reversal disorders is copy number variation of SOX3 (CNV) in previous reports. To date, 6 cases of SOX3 CNV related 46,XX male patients have been reported. In some cases, CNV duplication, including the SOX3 gene[39,41,42], resulted in the change of gene product dose. Some CNVS do not contain the SOX3 gene but are adjacent to the SOX3 gene region, or the breaking point of CNV falls in the regulatory region of $S O X 3$, so it is speculated that CNV has a positional effect on SOX3 gene expression[9,43]. The elemental clinical manifestations of the patient include sexual reversal and gonadal dysplasia, azoospermia and infertility(adult individual), which may be combined with other abnormal clinical phenotypes if other genes are present. CMA showed that our patient had a heterozygous deletion of about 867kb in Xq27.1 (hg19: chrX: 138,612,879$139,480,163 \mathrm{bp}$ ), which was located at 104kb downstream of the SOX3 gene, including F9, CXorf66, MCF2 and ATP11C; Meanwhile, whole-genome sequencing also found an 892kb heterozygosity deletion in Xq27.1 (hg19: chrX: 138,609,392-139,501,392), but no SNV\&InDel mutation associated with abnormal sex development. This patient is the first report of whole-genome sequencing in $46, X X$ male patients, and the use of WGA can entirely exclude pathogenic or likely pathogenic SNV\&InDel variants in genes associated with the patient's abnormal sexual phenotype. About this deletion area, no similar report was found in the DGV database of the normal population, and no sexual reversal phenotype was reported in Decipher and ClinVar databases. Similar to previous reports[9,41], we speculated that the deletion region might involve the regulation region of the $S O X 3$ gene, leading to differentiation and development of male testis through weakening inhibition of $S O X 3$ and increasing expression $S O X 3[9,42]$.

Since the deletion of the patient in this study occurred on the $X$ chromosome, the inactivation of the $X$ chromosome is also an essential factor affecting the clinical significance. $\mathrm{XCl}$ is a dose-compensation mechanism, which usually occurs in early embryonic development when one of the two X chromosomes in a woman is inactivated, resulting in only one paternal or maternal chromosome being expressed in each cell of the female individual. In general, $\mathrm{XCl}$ is random, i.e., the ratio of the two $\mathrm{X}$ chromosomes inactivated in females is $50 \%: 50 \%[44]$. However, if the inactivation is not random, it is called skewed inactivation. In 46,XX (SRY+) males, some studies[27,45] showed a high degree of XCl bias (greater than $90 \%$ ), some were random $X C l$ in other patients[46]. The phenotype of $46, X X$ males ( $S R Y+$ ) differed with the variable inactivation of the $\mathrm{X}$ chromosome carrying the $S R Y$ gene[47,48]. However, $\mathrm{XCl}$ has not been 
reported in 46,XX male( $S R Y$-)patients, so we conducted the XCl analysis in our patient. The XCl test found a moderate $\mathrm{XCl}$ bias; about $75 \%$ of $\mathrm{X}$ chromosomes in the patient's peripheral blood were inactivated. We speculate that the expression of positive selection of the deficient $X$ chromosomes results in the development of male gonads of the patient, similar to previous reports[49]. Since the sample of the patient's mother could not be collected, it is unknown whether the patient's $\mathrm{X}$ chromosome deletions are de novo or inherited from an unphenotypic mother (the XCI bias inactivates the abnormal $\mathrm{X}$ chromosome). The $\mathrm{XCl}$ ratio of gonads tissues may differ from peripheral blood[28], but it cannot be accurately known because the sample is inaccessible.

Similar to the two adults patients reported by Sutton E et al.[9], the main features of our patient are azoospermia and infertility[50] because of a deletion of the entire $Y$ chromosome, namely deletion of $A Z F$ region, contained USP9Y, DBY, PRY, RBMY, DAZ, BPY2 and other genes related to sperm production, development and maturation. $A Z F$ region is recognized as the most common factor of male infertility[5153], which account for $10 \%-15 \%$ of azoospermia and $5 \%-10 \%$ of severe oligozoospermia[54].

At present, the pathogenesis of $S R Y$ positive $46, \mathrm{XX}$ male patients is relatively straightforward. However, the molecular mechanism, signalling pathway and genetic regulation of $S R Y$ negative $46, X X$ male are not understood enough, and the diagnosis and treatment of these patients are still relatively complex. Sutton et al.[9] identified three arrangements including or adjacent to the SOX3 gene, accounting for $19 \%(3 / 16)$ in $16 S R Y$-negative $46, X X$ male patients. Subsequently, several case reports indicated that $S O X 3$ is a critical pathogenic factor in $S R Y$ negative $46, X X$ male patients. Therefore, it is crucial to conduct the CNV determination involved in the $S O X 3$ gene in all $S R Y$ negative $46, X X$ male patients. It is noteworthy that the current and reported SOX3 duplications or deletions are below the detection threshold of conventional karyotype and were found only by analyzing CNVs using CMA. Therefore, CMA detection is routinely recommended to detect $\mathrm{CNVs}$, and high-throughput sequencing can simultaneously rule out other SNV/INDEL mutations. In addition, the XCI test in XX diseases also should be considered.

\section{Declarations}

\section{Acknowledgements}

The authors thank all staff of Department of Medical Genetics and Prenatal Diagnosis for their assistance.

\section{Authors' contributions}

Shengfang Qin conceived and designed the study, interpreted the data and drafted the manuscript. Xueyang Wang enrolled the patients, performed genetic counseling and provided clinical information. Jin Wang performed the laboratory detection and experimental data acquisition.

\section{Funding}


This work was supported by the Science and Technology Innovation Funds (CXZD01-2020) of Sichuan Provincial Maternity and Child Health Care Hospital. .

\section{Availability of data and materials}

The datasets used and analysed during the current study are available from the corresponding author on reasonable request.

\section{Ethics approval and consent to participate}

The research was approved by the Institutional Committee for the Protection of Human Subjects (Institutional Review Board of Sichuan Provincial Maternity and Child Health Care Hospital, 2020111398), and the patient signed the informed consent.

\section{Consent for publication}

The patient had provided his consent for publication.

\section{Competing interests}

The authors declare that they have no competing interests.

\section{References}

1. Lee PA, Houk CP, Ahmed SF, Hughes IA. Consensus statement on management of intersex disorders. International Consensus Conference on Intersex. Pediatrics. 2006;118(2):e488-500. https://doi.org/10.1542/peds.2006-0738

2. DELACHAPELLE A, HORTLING H, NIEMI M, WENNSTROEM J. XX SEX CHROMOSOMES IN A HUMAN MALE. FIRST CASE. Acta Med Scand. 1964;175:SUPPL 412:25-8. https://doi.org/10.1111/j.09546820.1964.tb04630.x.

3. Andersson M, Page DC, de la Chapelle A. Chromosome Y-specific DNA is transferred to the short arm of X chromosome in human XX males. Science. 1986;233(4765):786-8.

https://doi.org/10.1126/science.3738510.

4. Ferguson-Smith MA, Cooke A, Affara NA, Boyd E, Tolmie JL. Genotype-phenotype correlations in XX males and their bearing on current theories of sex determination. Hum Genet. 1990;84(2):198-202. https://doi.org/10.1007/BF00208942.

5. Donlon TA, Müller U. Deletion mapping of DNA segments from the $Y$ chromosome long arm and their analysis in an XX male. Genomics. 1991;10(1):51-6. https://doi.org/10.1016/0888-7543(91)90483-u.

6. Vorona E, Zitzmann M, Gromoll J, Schüring AN, Nieschlag E. Clinical, endocrinological, and epigenetic features of the 46,XX male syndrome, compared with 47,XXY Klinefelter patients. J Clin Endocrinol 
Metab. 2007;92(9):3458-65. https://doi.org/10.1210/jc.2007-0447.

7. Ahmad A, Siddiqui MA, Goyal A, Wangnoo SK. Is 46XX karyotype always a female. BMJ Case Rep. 2012;2012. https://doi.org/10.1136/bcr-2012-006223.

8. Inoue $H$, Nomura $M$, Yanase $T$, Ichino I,Goto $K$, Ikuyama S, et al. A rare case of $46, X X$ true hermaphroditism with hidden mosaicism with sex-determining region $Y$ chromosome-bearing cells in the gonads. Intern Med. 1998;37(5):467-71. https://doi.org/10.2169/internalmedicine.37.467.

9. Sutton E, Hughes J, White S, Sekido R, Tan J, Arboleda V, et al. Identification of SOX3 as an XX male sex reversal gene in mice and humans. J Clin Invest. 2011;121(1):328-41. https://doi.org/10.1172/JCl42580.

10. Cox JJ, Willatt L, Homfray T, Woods CG. A SOX9 duplication and familial 46,XX developmental testicular disorder. N Engl J Med. 2011;364(1):91-3. https://doi.org/10.1056/NEJMc1010311.

11. Kim GJ, Sock E, Buchberger A, Just W, Denzer F, Hoepffner W, et al. Copy number variation of two separate regulatory regions upstream of SOX9 causes isolated $46, X Y$ or $46, X X$ disorder of sex development. J Med Genet. 2015;52(4):240-7. https://doi.org/10.1136/jmedgenet-2014-102864

12. Mengen E, Kayhan G, Kocaay P, Uçaktürk SA. A Duplication Upstream of SOX9 Associated with SRY Negative 46,XX Ovotesticular Disorder of Sex Development: A Case Report. J Clin Res Pediatr Endocrinol. 2020;12(3):308-14. https://doi.org/10.4274/jcrpe.galenos.2019.2019.0101

13. Parma P, Radi O, Vidal V, Chaboissier MC, Dellambra E, Valentini S, et al. R-spondin 1 is essential in sex determination, skin differentiation and malignancy. Nat Genet. 2006;38(11):1304-9.

https://doi.org/10.1038/ng1907

14. Lee GM, Ko JM, Shin $\mathrm{CH}$, Yang SW. A Korean boy with $46, \mathrm{XX}$ testicular disorder of sex development caused by SOX9 duplication. Ann Pediatr Endocrinol Metab. 2014;19(2):108-12. https://doi.org/10.6065/apem.2014.19.2.108

15. Mandel H, Shemer R, Borochowitz ZU, Okopnik M, Knopf C, Indelman M, et al. SERKAL syndrome: an autosomal-recessive disorder caused by a loss-of-function mutation in WNT4. Am J Hum Genet. 2008;82(1):39-47. https://doi.org/10.1016/j.ajhg.2007.08.005

16. Baetens D, Stoop H, Peelman F, Todeschini AL, Rosseel T, Coppieters F, et al. NR5A1 is a novel disease gene for 46,XX testicular and ovotesticular disorders of sex development. Genet Med. 2017;19(4):367-76. https://doi.org/10.1038/gim.2016.118

17. Igarashi M, Takasawa K, Hakoda A, Kanno J, Takada S, Miyado M, et al. Identical NR5A1 Missense Mutations in Two Unrelated 46,XX Individuals with Testicular Tissues. Hum Mutat. 2017;38(1):39-42. https://doi.org/10.1002/humu.23116 
18. Bashamboo A, Donohoue PA, Vilain E, Rojo S, Calvel P, Seneviratne SN, et al. A recurrent p.Arg92Trp variant in steroidogenic factor-1 (NR5A1) can act as a molecular switch in human sex development. Hum Mol Genet. 2016;25(16):3446-53. https://doi.org/10.1093/hmg/ddw186.

19. Liu Y, Kong XD, Wu QH, Li G, Song L, Sun YP. Karyotype analysis in large-sample infertile couples living in Central China: a study of 14965 couples. J Assist Reprod Genet. 2013;30(4):547-53. https://doi.org/10.1007/s10815-013-9964-6.

20. Masoudzadeh N, Teimourian S. Comparison of quantitative fluorescent polymerase chain reaction and karyotype analysis for prenatal screening of chromosomal aneuploidies in 270 amniotic fluid samples. J Perinat Med. 2019;47(6):631-6. https://doi.org/10.1515/jpm-2019-0069.

21. Song $Y$, Chen Q, Zhang Z, Hou H, Zhang D, Shi Q. Effects of age on segregation of the $X$ and $Y$ chromosomes in cultured lymphocytes from Chinese men. J Genet Genomics. 2009;36(8):467-74. https://doi.org/10.1016/S1673-8527(08)60136-8.

22. Chen S, Zhou Y, Chen Y, Gu J. fastp: an ultra-fast all-in-one FASTQ preprocessor. Bioinformatics. 2018;34(17):i884-884i890. https://doi.org/10.1093/bioinformatics/bty560.

23. Li H, Durbin R. Fast and accurate short read alignment with Burrows-Wheeler transform. Bioinformatics. 2009;25(14):1754-60. https://doi.org/10.1093/bioinformatics/btp324.

24. García-Alcalde F, Okonechnikov K, Carbonell J, Cruz LM, Götz S, Tarazona S, et al. Qualimap: evaluating next-generation sequencing alignment data. Bioinformatics. 2012;28(20):2678-9. https://doi.org/10.1093/bioinformatics/bts503.

25. Koboldt DC, Zhang Q, Larson DE, Shen D, McLellan MD, Ling Lin L, et al. VarScan 2: somatic mutation and copy number alteration discovery in cancer by exome sequencing. Genome Res. 2012;22(3):568-76. https://doi.org/10.1101/gr.129684.111.

26. Allen RC, Zoghbi HY, Moseley AB, Rosenblatt HM, Belmont JW. Methylation of Hpall and Hhal sites near the polymorphic CAG repeat in the human androgen-receptor gene correlates with $\mathrm{X}$ chromosome inactivation. Am J Hum Genet. 1992;51(6):1229-39.

27. Bouayed Abdelmoula N, Portnoi MF, Keskes L, Recan D, Bahloul A, Boudawara T, et al. Skewed Xchromosome inactivation pattern in SRY positive XX maleness: a case report and review of literature. Ann Genet. 2003;46(1):11-8. https://doi.org/10.1016/s0003-3995(03)00011-x.

28. Sharp A, Robinson D, Jacobs $P$. Age- and tissue-specific variation of $X$ chromosome inactivation ratios in normal women. Hum Genet. 2000;107(4):343-9. https://doi.org/10.1007/s004390000382.

29. Minks J, Robinson WP, Brown CJ. A skewed view of $X$ chromosome inactivation. J Clin Invest. 2008;118(1):20-3. https://doi.org/10.1172/JCl34470. 
30. Mizuno K, Kojima Y, Kamisawa H, Moritoki Y, Nishio H, Nakane A, et al. Elucidation of distinctive genomic DNA structures in patients with 46,XX testicular disorders of sex development using genome wide analyses. J Urol. 2014;192(2):535-41. https://doi.org/10.1016/j.juro.2014.02.044.

31. Stevanović M, Lovell-Badge R, Collignon J, Goodfellow PN. SOX3 is an X-linked gene related to SRY. Hum Mol Genet. 1993;2(12):2013-8. https://doi.org/10.1093/hmg/2.12.2013.

32. Collignon J, Sockanathan S, Hacker A, Cohen-Tannoudji M, Norris D, Rastan S, et al. A comparison of the properties of Sox-3 with Sry and two related genes, Sox-1 and Sox-2. Development. 1996;122(2):50920.

33. Foster JW, Graves JA. An SRY-related sequence on the marsupial X chromosome: implications for the evolution of the mammalian testis-determining gene. Proc Natl Acad Sci U S A. 1994;91(5):1927-31. https://doi.org/10.1073/pnas.91.5.1927.

34. Lagerström-Fermér M, Sundvall M, Johnsen E, Warne GL, Forrest SM, Zajac J D, et al. X-linked recessive panhypopituitarism associated with a regional duplication in Xq25-q26. Am J Hum Genet. 1997;60(4):910-6.

35. Laumonnier F, Ronce N, Hamel BC, Thomas P, Lespinasse J, Raynaud M, et al. Transcription factor SOX3 is involved in X-linked mental retardation with growth hormone deficiency. Am J Hum Genet. 2002;71(6):1450-5. https://doi.org/10.1086/344661.

36. Rizzoti K, Brunelli S, Carmignac D, Thomas PQ, Robinson IC, Lovell-Badge R. SOX3 is required during the formation of the hypothalamo-pituitary axis. Nat Genet. 2004;36(3):247-55.

https://doi.org/10.1038/ng1309.

37. Solomon NM, Ross SA, Forrest SM, Thomas PQ, Morgan T, Belsky JL, et al. Array comparative genomic hybridisation analysis of boys with X-linked hypopituitarism identifies a $3.9 \mathrm{Mb}$ duplicated critical region at Xq27 containing SOX3. J Med Genet. 2007;44(4):e75. https://doi.org/10.1136/jmg.2007.049049.

38. Laronda MM, Jameson JL. Sox3 functions in a cell-autonomous manner to regulate spermatogonial differentiation in mice. Endocrinology. 2011;152(4):1606-15. https://doi.org/10.1210/en.2010-1249.

39. Moalem S, Babul-Hirji R, Stavropolous DJ, Wherrett D, Bägli DJ, Thomas P, et al. XX male sex reversal with genital abnormalities associated with a de novo SOX3 gene duplication. Am J Med Genet A. 2012;158A(7):1759-64. https://doi.org/10.1002/ajmg.a.35390.

40. Igarashi M, Mikami H, Katsumi M, Miyado M, Izumi Y, Ogata T, et al. SOX3 Overdosage Permits Normal Sex Development in Females with Random X Inactivation. Sex Dev. 2015;9(3):125-9. https://doi.org/10.1159/000377653. 
41. Grinspon RP, Nevado J, Mori Alvarez Mde L, Rey GD, Castera R, Venara M, et al. 46,XX ovotesticular DSD associated with a SOX3 gene duplication in a SRY-negative boy. Clin Endocrinol (Oxf). 2016;85(4):673-5. https://doi.org/10.1111/cen.13126.

42. Tasic V, Mitrotti A, Riepe FG, Kulle AE, Laban N, Polenakovic M, et al. Duplication of The SOX3 Gene in an Sry-negative 46,XX Male with Associated Congenital Anomalies of Kidneys and the Urinary Tract: Case Report and Review of the Literature. Balkan J Med Genet. 2019;22(1):81-8. https://doi.org/10.2478/bjmg2019-0006.

43. Bowl MR, Nesbit MA, Harding B, Levy E, Jefferson A, Volpi E, et al. An interstitial deletion-insertion involving chromosomes 2p25.3 and Xq27.1, near SOX3, causes X-linked recessive hypoparathyroidism. J Clin Invest. 2005;115(10):2822-31. https://doi.org/10.1172/JCl24156.

44. Amos-Landgraf JM, Cottle A, Plenge RM, Friez M, Schwartz CE, Longshore J, et al. X chromosomeinactivation patterns of 1,005 phenotypically unaffected females. Am J Hum Genet. 2006;79(3):493-9. https://doi.org/10.1086/507565.

45. Kusz K, Kotecki M, Wojda A, Szarras-Czapnik M, Latos-Bielenska A, Warenik-Szymankiewicz A, et al. Incomplete masculinisation of XX subjects carrying the SRY gene on an inactive X chromosome. J Med Genet. 1999;36(6):452-6.

46. Gunes S, Asci R, Okten G, Atac F, Onat OE, Ogur G, et al. Two males with SRY-positive 46,XX testicular disorder of sex development. Syst Biol Reprod Med. 2013;59(1):42-7.

https://doi.org/10.3109/19396368.2012.731624.

47. McElreavey K, Rappaport R, Vilain E, Abbas N, Richaud F, Lortat-Jacob S, et al. A minority of 46,XX true hermaphrodites are positive for the Y-DNA sequence including SRY. Hum Genet. 1992;90(1-2):121-5. https://doi.org/10.1007/BF00210754.

48. McElreavey K, Vilain E, Abbas N, Herskowitz I, Fellous M. A regulatory cascade hypothesis for mammalian sex determination: SRY represses a negative regulator of male development. Proc Natl Acad Sci U S A. 1993;90(8):3368-72. https://doi.org/10.1073/pnas.90.8.3368.

49. Fechner PY, Rosenberg C, Stetten G, Cargile CB, Pearson PL, Smith KD, et al. Nonrandom inactivation of the $\mathrm{Y}$-bearing X chromosome in a 46,XX individual: evidence for the etiology of $46, \mathrm{XX}$ true hermaphroditism. Cytogenet Cell Genet. 1994;66(1):22-6. https://doi.org/10.1159/000133656.

50. Vetro A, Ciccone R, Giorda R, Patricelli MG, Mina ED, Forlino A, et al. XX males SRY negative: a confirmed cause of infertility. J Med Genet. 2011;48(10):710-2. https://doi.org/10.1136/jmedgenet-2011100036.

51. Tiepolo L, Zuffardi O. Localization of factors controlling spermatogenesis in the nonfluorescent portion of the human Y chromosome long arm. Hum Genet. 1976;34(2):119-24. 
https://doi.org/10.1007/BF00278879.

52. Motovali-Bashi M, Rezaei Z, Dehghanian F, Rezaei H. Multiplex PCR based screening for micro/partial deletions in the AZF region of Y-chromosome in severe oligozoospermic and azoospermic infertile men in Iran. Iran J Reprod Med. 2015;13(9):563-70.

53. Colaco S, Modi D. Genetics of the human Y chromosome and its association with male infertility. Reprod Biol Endocrinol. 2018;16(1):14. https://doi.org/10.1186/s12958-018-0330-5.

54. Yu XW, Wei ZT, Jiang YT, Zhang SL. Y chromosome azoospermia factor region microdeletions and transmission characteristics in azoospermic and severe oligozoospermic patients. Int J Clin Exp Med. 2015;8(9):14634-46.

\section{Tables}

Table 1 Comparison of the clinical phenotypes of 46,XX SRY-negative male patients with CNV of SOX3. 


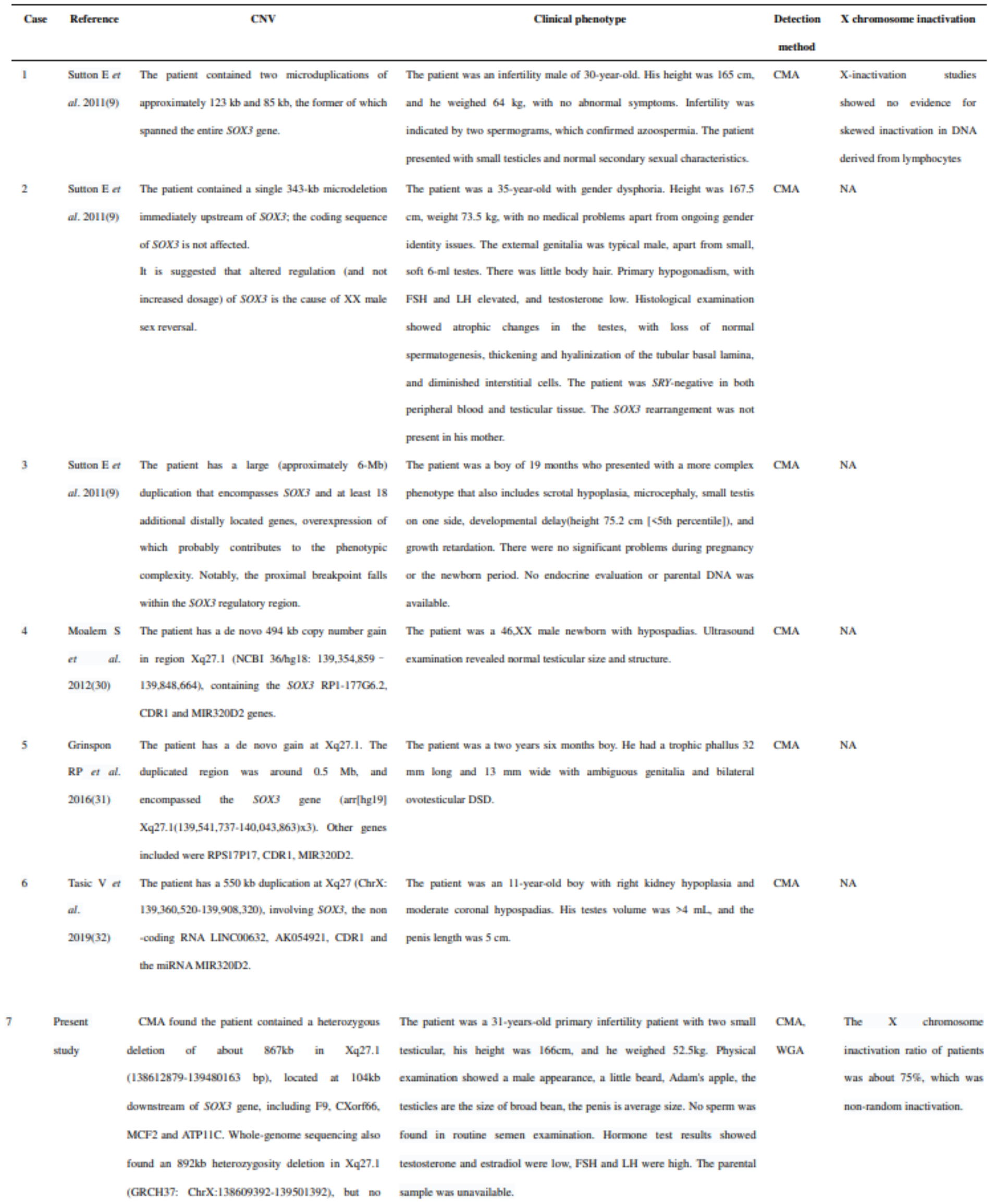


SNV\&InDel mutation associated with abnormal sex

\section{Figures}

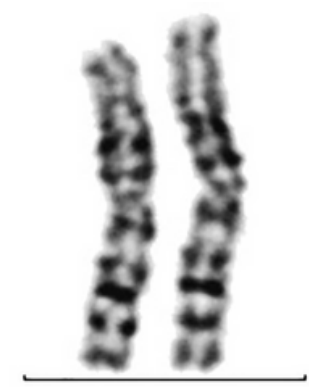

1

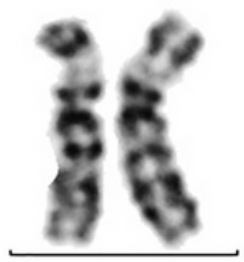

6

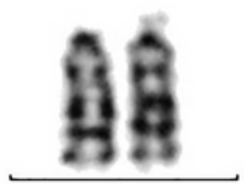

13

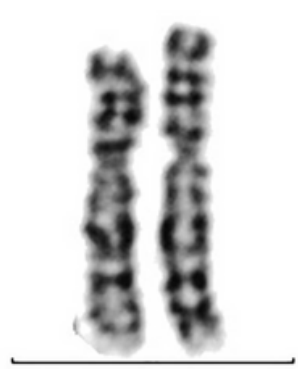

2

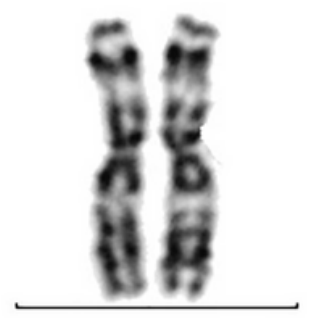

3
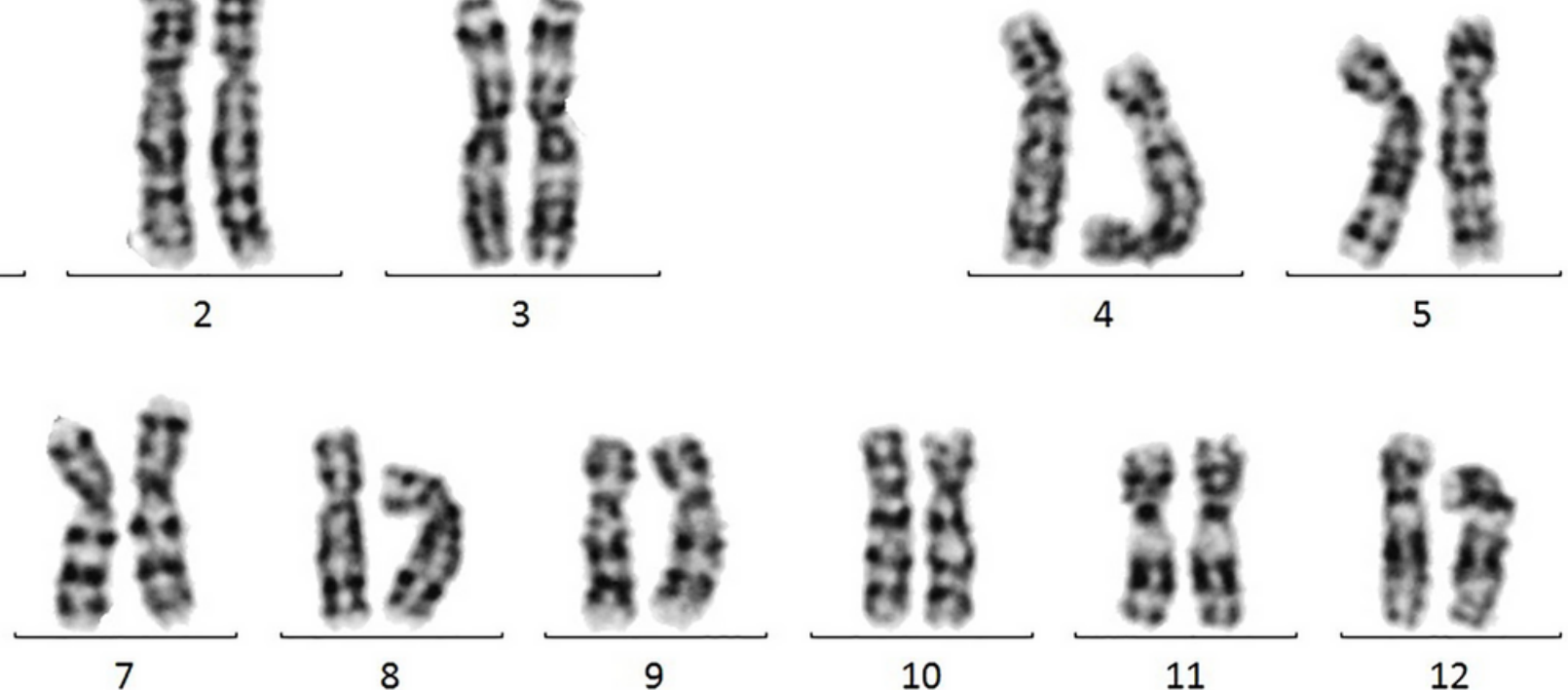

8

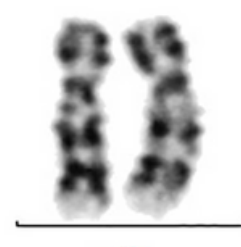

9

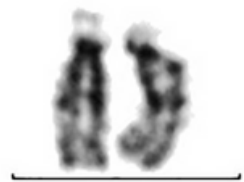

15

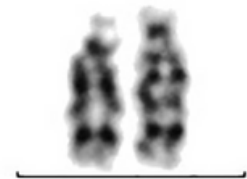

14

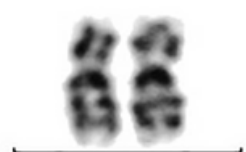

16
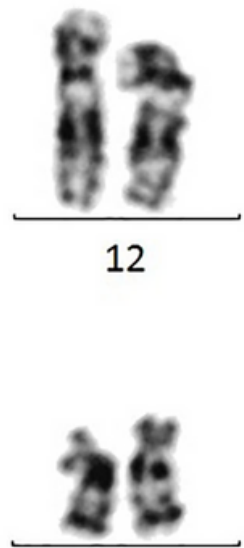

18
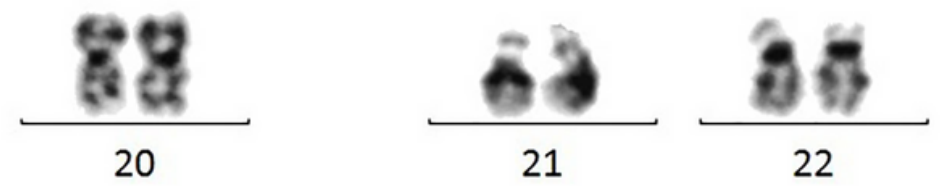

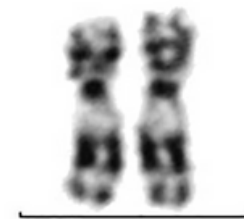

11

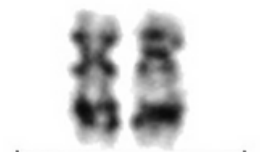

17

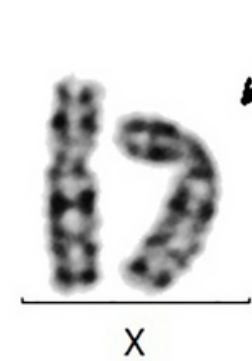

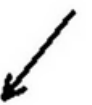

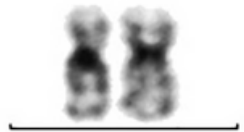

19

20

Figure 1

Chromosome karyotype of the patient. The sex chromosome of $46, \mathrm{XX}$ male sex reversal patient is $\mathrm{XX}$, as the arrow indicated, but no $Y$ chromosome. 

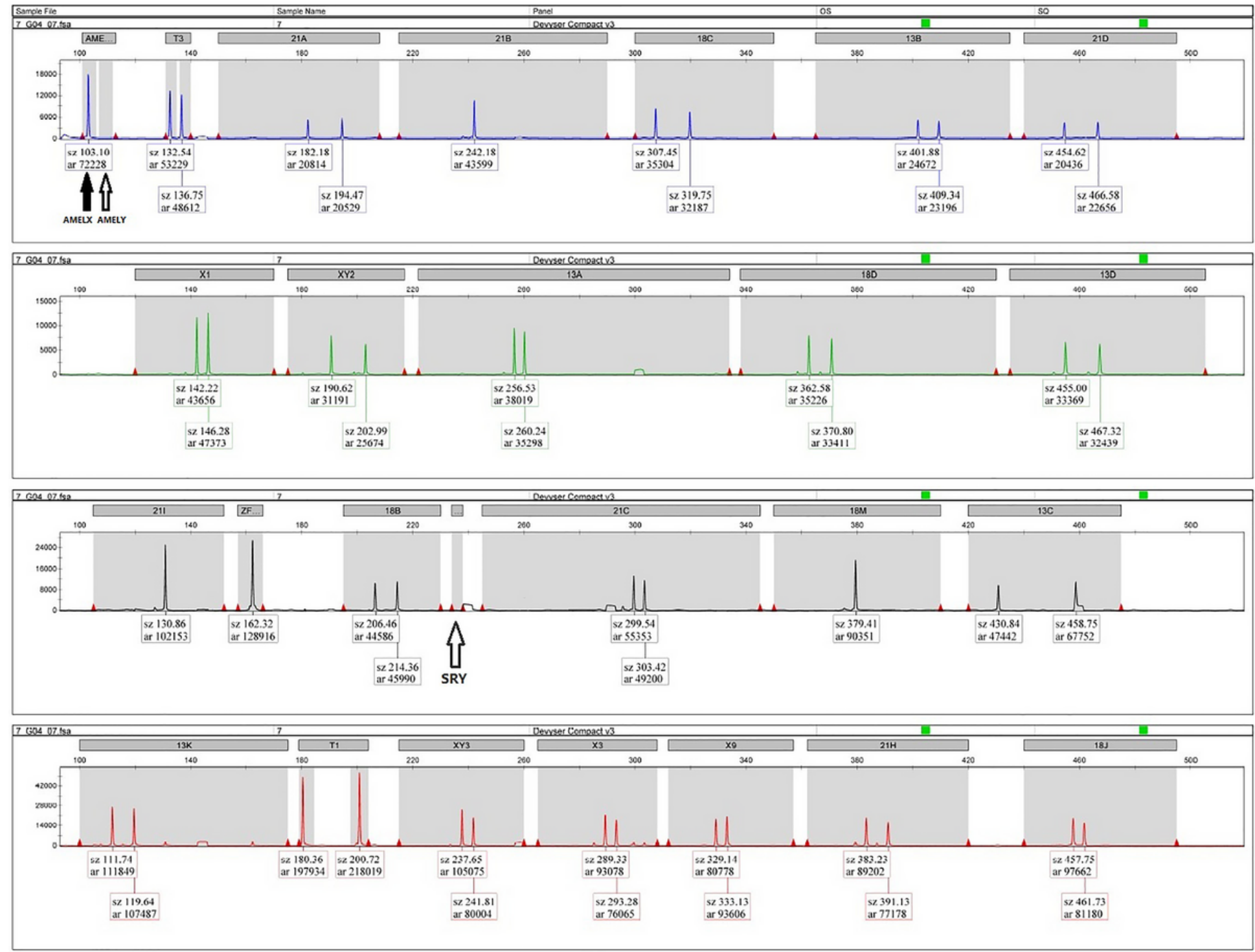

Figure 2

QF-PCR electrophoresis diagram of the 46,XX (SRY-) male patient. QF-PCR results of the patient showed a fluorescence peak of AMELX but no AMELXY and SRY. AMELX, AMELXY and SRY represent the loci of Xp22.2, Yp11.2 and Yp11.31, respectively. The solid arrow indicated a specific amplification peak, while the hollow arrow indicated no amplification peak. 


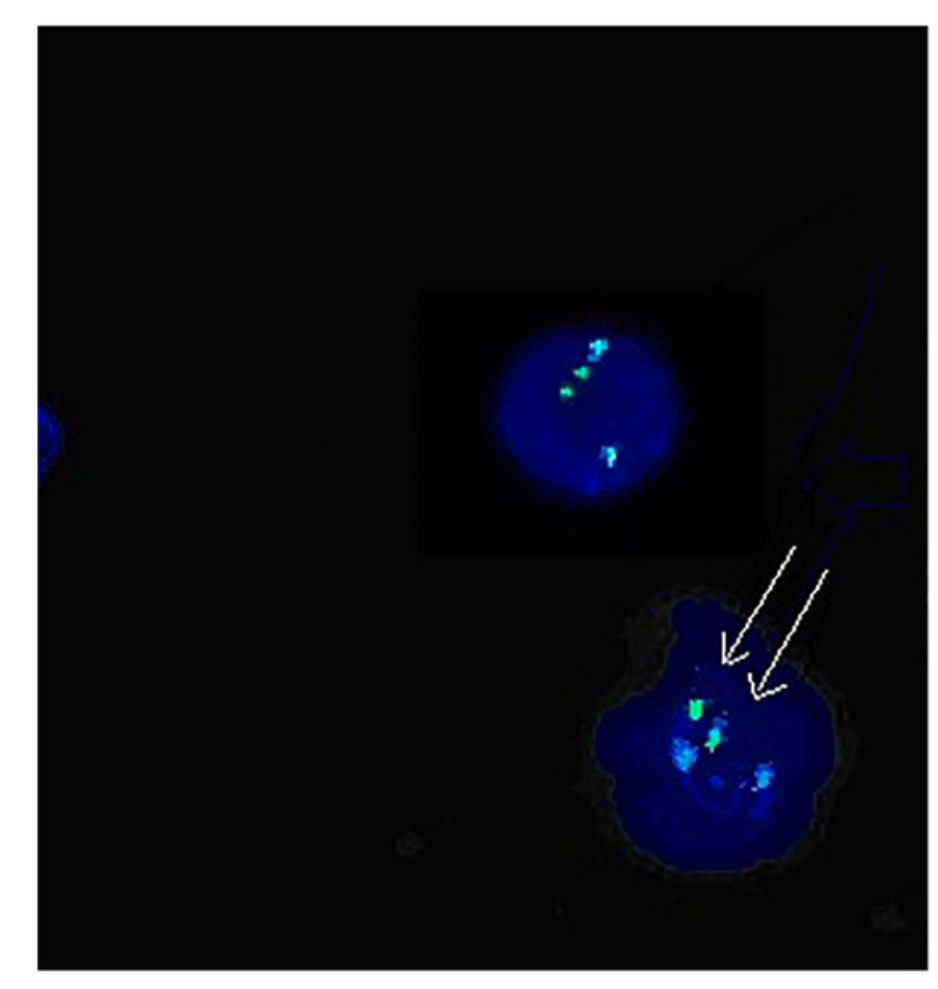

A

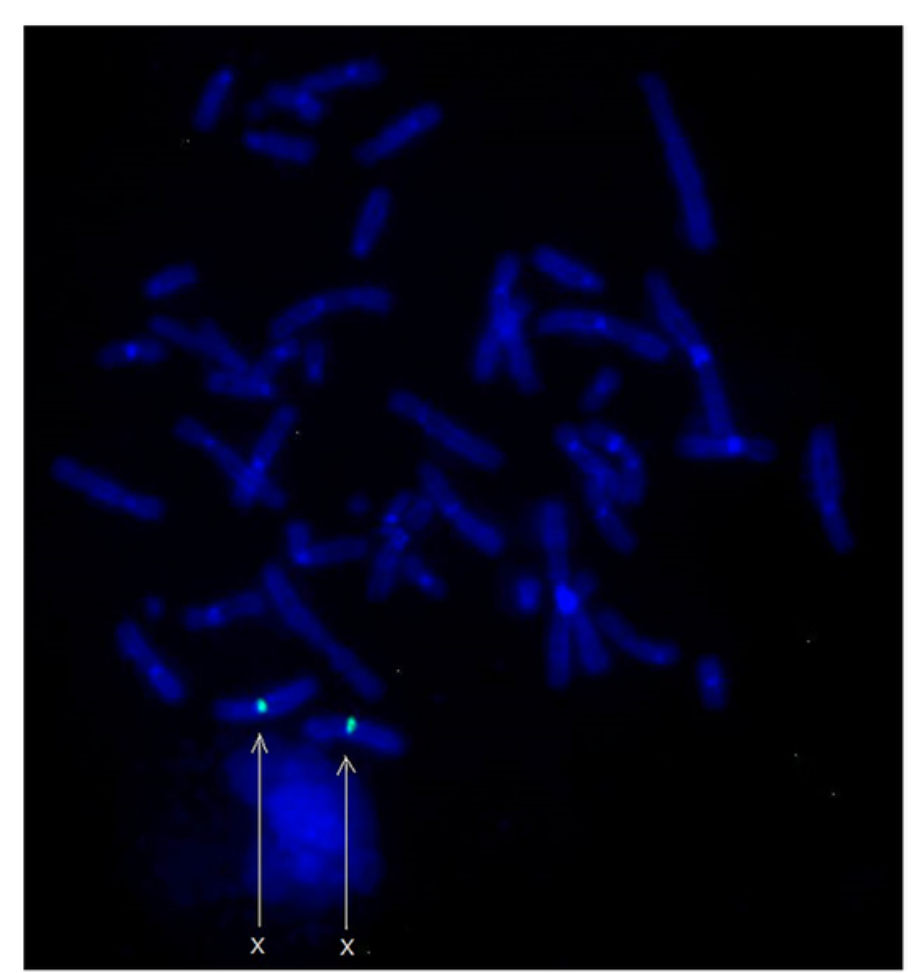

B

\section{Figure 3}

a. Interphase cells FISH of the 46,XX (SRY-) male patient using 18, X, and Y centromeric probes. The blue signal represents the centromeres on chromosome 18, while the green signal represents the centromeres on chromosome X, as indicated by the arrow b. Metaphase cells FISH of the 46,XX (SRY-) male patient with $\mathrm{X}, \mathrm{Y}$ and SRY probes. The green signal represents the centromeres of the $\mathrm{X}$ chromosome, as indicated by the arrow. 


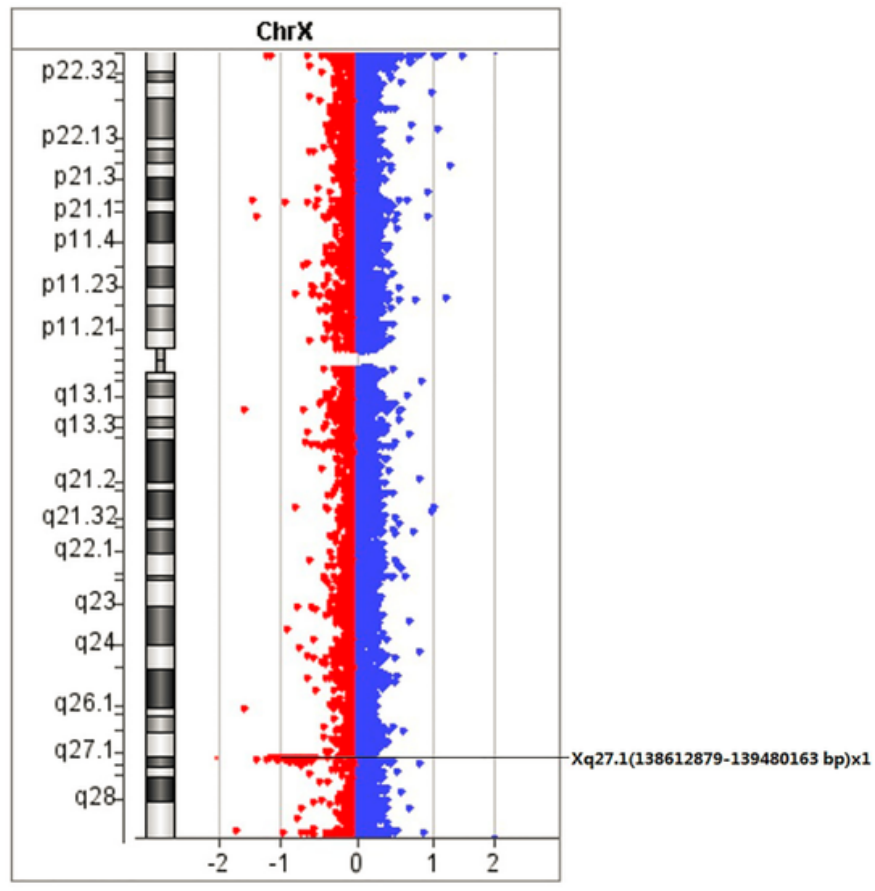

A

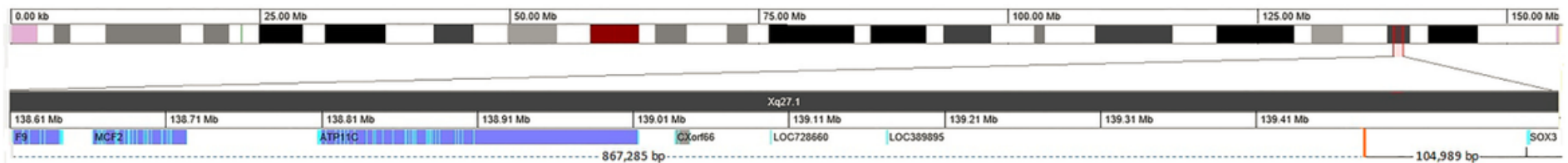

B

Figure 4

a. CMA results of the $46, X X$ (SRY-) male patient. There was about $867 \mathrm{~kb}$ heterozygous loss in Xq27.1 (hg19: chrX: 138,612,879-139,480,163bp), as the line indicated. b. Schematic diagram of gene chip deletion region of the 46,XX (SRY-) male patient. The deletion region (hg19: chrX: 138,612,879$139,480,163 \mathrm{bp}$ ) is located at 104kb downstream of the SOX3 gene in Xq27.1. The dotted line is the deletion region with a size of about $867 \mathrm{~kb}$. 


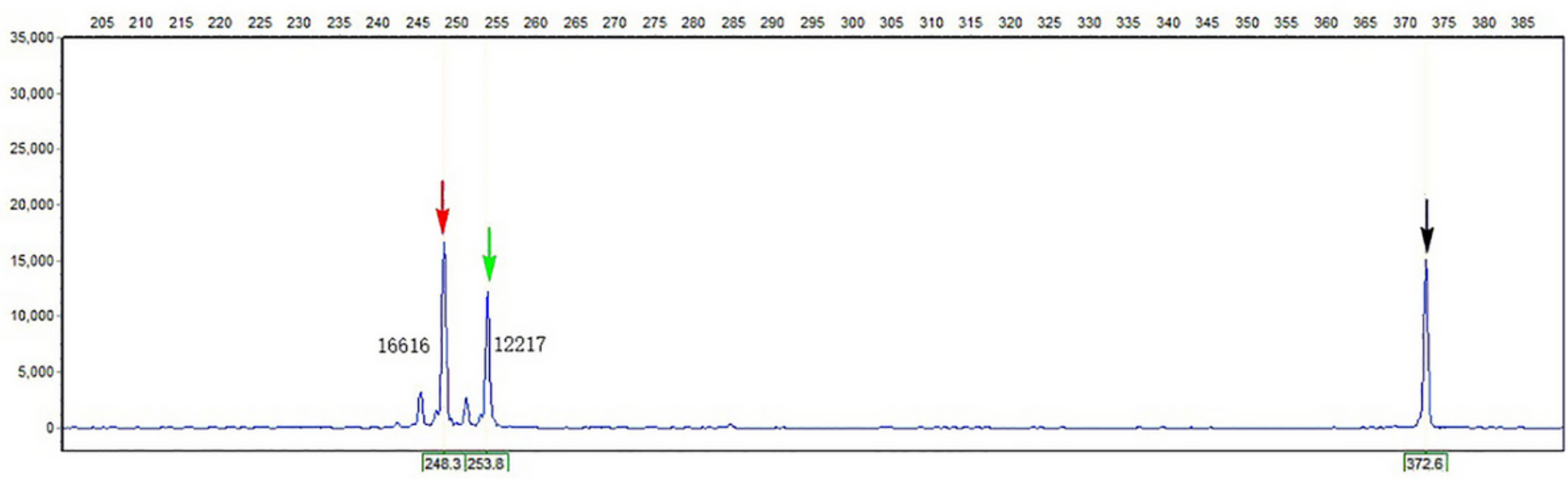

\section{After diqestion}

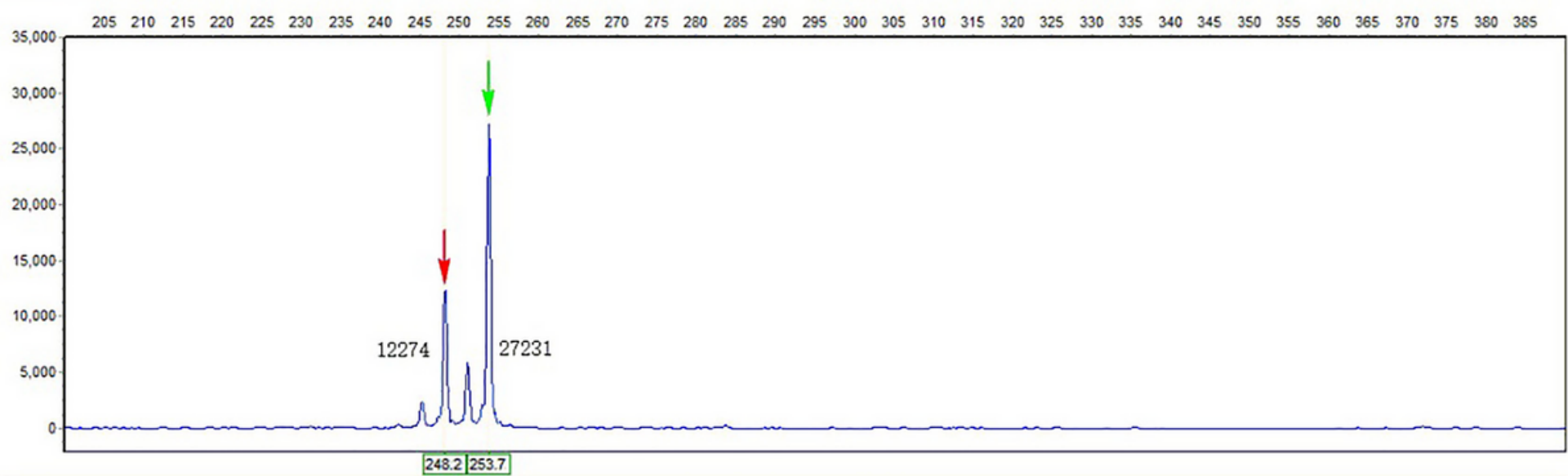

\section{Figure 5}

X chromosome inactivation results of the 46,XX (SRY-) male patient. The figure above and below show the fluorescence peaks of the $\mathrm{X}$ chromosome before and after Hpall digestion, respectively. The ordinate and abscissa represent fluorescence intensity and fragment length. The black arrow indicates the amplified products of the reference gene. After complete digestion, there is no amplified products peak (as shown below). The red and green arrows indicate the two alleles of the AR gene in the $X$ chromosomes. $X$ chromosome inactivation was calculated according to the formula (d1/u1)/(d1/u1 $+d 2 / u 2)$. The $X$ chromosome inactivation rate in this patient was about $75 \%$, which was non-random. $d 1$ : the height of the higher peak after enzyme digestion, u1: the height of the undigested peak, which corresponding to $d 1 ; d 2$ : the height of the shorter peak after digestion; $u 2$ : the height of the undigested peak, which corresponding to d2. 